\title{
COMPARISON OF SIMPLE VISUAL AND AUDIOTORY REACTION TIMES OF MARTIAL ARTS ATHLETES ${ }^{i}$
}

\author{
Irfan Tamer Mülhim, \\ Frrat Akcan ii \\ Gaziantep University, \\ Physical Education and Sport Faculty, \\ Gaziantep, Turkey
}

\begin{abstract}
:
Many fitness skills are required to be successful in martial arts sports. It is known that the reaction time is distinctive for performance in all martial arts, although the specific importance of different motoric features in sports branches is variable. The aim of this study is to compare simple visual and auditory reaction times of martial arts athletes. For this purpose, 48 male athletes between the ages of 15 and 25 who have been actively doing sports for at least 1 year in boxing, judo, karate, muay thai, kickboxing and taekwondo branches were voluntarily included in the study. Height, body weight, simple visual and auditory reaction time measurements were made by obtaining the age and year of starting sports of the athletes. There was no statistically significant difference between the visual and auditory reaction times according to the participants' age, body mass index and sports age variables $(\mathrm{p}<0.05)$. There was a statistically significant difference between the visual reaction times according to the success level variable of the participants, but no significant difference was found between the auditory reaction times $(p<0.05)$. In terms of the sport branch variable of the participants, a statistically significant difference was found between the visual and auditory reaction times $(\mathrm{p}<0.05)$. Accordingly, it can be said that the visual reaction times of the athletes improve as the level of success increases, and the visual and auditory reaction times are more important in martial arts athletes (muay thai, karate taekwondo, kickboxing and boxing) where quickness, movement frequency and movement speed are important. As a result, it is thought that martial arts athletes who want to increase their level of success should include reaction time studies in their training programs. However, it is suggested that it would be beneficial to apply such studies to larger groups and to include women.
\end{abstract}

Keywords: martial arts athletes, visual reaction, auditory reaction

\footnotetext{
' This article is adapted from the thesis study entitled Comparison of simple visual and auditory reaction times of martial arts athletes.

ii Correspondence: email akcanfirat@yahoo.com
} 


\section{Introduction}

Sports is a very important physical activity to increase the quality of life of people and as a result of these activities, people can be physically and mentally healthy (1). Regular exercise has the potential to improve human health and physical fitness (2). In addition, the exercise serves success in both provincial, national or international championships. The power of nations is now seen not only in terms of welfare, education, economic and military, but also in the form of sporting success ( $\underline{3})$.

When the historical process is examined, martial arts, which started in the struggle of man with nature from very ancient times, and emerged from wars and the struggle of man with his environment, over time turned into a sport with the element of competition and rules. Looking at the historical development of martial arts sports, it is seen that they emerged for similar reasons in different geographical regions and were shaped by regional characteristics ( $\underline{4})$.

Martial arts are activities that combine sports and artistic elements, are associated with the tradition of hand-to-hand combat, or are practiced unarmed, using specific tools whose main purpose is to protect oneself from physical attacks (ㅁ). Besides selfprotection, it is also used for children's education, character development, physical fitness, mental strength, spirituality and achievement (ㅁ).

Some of the dominant physical components for martial arts athletes that must be continually trained are reaction, coordination, and speed. These three things are closely related to some techniques needed in martial arts namely kick technique, punch technique and defensive technique. A good response will benefit the athlete in attacking with both kicks and punches. Fast reaction time will produce a good reaction speed, especially to visual stimulus, it is very important to have a good reaction speed in martial arts, so it will benefit the athlete to score points ( $\underline{7})$.

Reaction time is a true indicator of a person's hand-eye coordination, reaction and alertness. Most of the work in sports and daily life is done using auditory and visual information. Reaction time is a measure of how quickly certain tasks are done (ㅁ). Athletes are known to have better reaction times than non-athletes. Reaction time is a determining factor affecting success in sports competitions. The reaction times of the athletes vary in different sports branches (ㅁ).

The main purpose of the trainings prepared by trainers, conditioners and sports psychologists for athletes; it is the achievement of great success in training and competitions by developing the conditional and mental characteristics of the athletes specific to the sport branch. New approaches and training programs are designed for athletes to achieve high performance in competitions ( $\underline{9})$.

It is thought that determining the reaction times of athletes in different branches in martial arts and knowing whether this is affected by various variables will contribute to the scientific literature. At the same time, it can be stated that knowing whether there is a difference between the reaction times of the athletes in different sports branches can contribute to the literature. 


\section{Material and Method}

The research is a scanning design and aimed to compare the simple visual and auditory reaction times of martial arts athletes. Forty-eight male athletes residing in Gaziantep, between the ages of 15 and 25, who have been actively doing sports in the branches of boxing, judo, karate, muay thai, kick boxing and taekwondo for at least 1 year, were voluntarily included.

\subsection{Collection of Data}

Height, body weight, simple visual and auditory reaction time measurements were made by obtaining the age and year of starting sports of the athletes. Specially developed software for the visual and auditory reaction times of the athletes were applied using the online environment (www.humanbenchmark.com, www.cognitivefun.net). The environment for the test was arranged by minimizing external influences. The application of the test was explained to the athletes. Afterwards, the athletes were allowed to get used to the test by applying the test. The test was started as soon as the athletes felt ready. Five trials were made for the visual and auditory reaction times of the athletes and their arithmetic average was taken (10-12).

\subsection{Statistical Analysis}

SPSS22 package program was used in the analysis of the data sets. Shapiro Wilk test was used to test the normality assumptions of the data sets. After the normality assumption was made, the mean and standard deviation values of the data were given. Pearson Correlation test was applied to test the relationship of the data sets with each other. In addition, the One Way Anova test was applied to understand whether there was a significant difference between the groups, and the LSD test, one of the Post Hoc tests, was

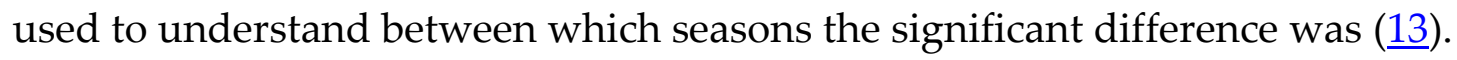

\section{Results}

Table 1: Descriptive Parameters of Participants

\begin{tabular}{|c|c|c|c|c|c|c|}
\hline \multirow{2}{*}{$\begin{array}{l}\text { Sport } \\
\text { branches }\end{array}$} & \multirow{2}{*}{$\mathbf{N}$} & Height $(\mathrm{cm})$ & Weight (kg) & BMI & Sport age & Degree of Success \\
\hline & & Mean. \pm S.D. & Mean. \pm S.D. & Mean. \pm S.D. & Mean. \pm S.D. & Mean. \pm S.D. \\
\hline Judo & \multirow{6}{*}{8} & $1,75 \pm 0,06$ & $66,88 \pm 0,44$ & $21,54 \pm 4,16$ & $2,62 \pm 0,74$ & $4,75 \pm 070$ \\
\hline Karate & & $1,72 \pm, 09$ & $68,38 \pm 16,68$ & $22,82 \pm 3,22$ & $4,38 \pm 1,30$ & $3,00 \pm 1,41$ \\
\hline Muay thai & & $1,76 \pm 0,06$ & $71,00 \pm 11,90$ & $22,66 \pm 3,04$ & $2,50 \pm 1,85$ & $4,13 \pm 1,80$ \\
\hline Kick box & & $1,73 \pm 0,07$ & $62,50 \pm 15,73$ & $20,53 \pm 4,31$ & $1,38 \pm 0,51$ & $5,25 \pm 1,03$ \\
\hline Taekwondo & & $1,79 \pm 0,06$ & $65,63 \pm 11,99$ & $20,30 \pm 2,99$ & $4,13 \pm 1,55$ & $3,25 \pm 1,58$ \\
\hline Boxing & & $1,74 \pm 0,06$ & $68,25 \pm 11,99$ & $22,52 \pm 2,53$ & $1,50 \pm 0,53$ & $4,88 \pm 1,35$ \\
\hline
\end{tabular}

When Table 1 is examined, the athletes in the branch of judo; mean height $1.75 \pm 0.06$, mean body weight $66.88 \pm 0.44$, mean body mass index $21.54 \pm 4.16$, mean age in sports $2.62 \pm 0.74$, mean achievement score 4 , It was determined as $75 \pm 070$. Athletes in karate branch; mean height $1.72 \pm 09$, mean body weight $68.38 \pm 16.68$, mean body mass index 
$22.82 \pm 3.22$, mean age in sports $2.50 \pm 1.85$, mean achievement score $3.00 \pm$ It was determined as 1.41. Athletes in the muay thai branch; mean height is $1.76 \pm 0.06$, mean body weight is $71.00 \pm 11.90$, mean body mass index is $22.66 \pm 3.04$, mean age in sports is $2.50 \pm 1.85$, mean achievement score is 4 . It was determined as $13 \pm 1.80$. Athletes in the Kickboxing branch; mean height $1.73 \pm 0.07$, mean body weight $62.50 \pm 15.73$, mean body mass index $20.53 \pm 4.31$, mean age in sports $1.38 \pm 0.51$, mean score of success 5 , It was determined as $25 \pm 1.03$. Athletes in Taekwondo branch; mean height $1.79 \pm 0.06$, mean body weight $65.63 \pm 11.99$, mean body mass index $20.30 \pm 2.99$, mean age in sports $4.13 \pm$ 1.55, mean score of success 3, It was determined as $25 \pm 1.58$. Athletes in the boxing branch; mean height is $1.74 \pm 0.06$, mean body weight is $68.25 \pm 11.99$, mean body mass index is $22.52 \pm 2.53$, mean age in sports is $1.50 \pm 0.53$, mean achievement score is 4 . It was determined as $88 \pm 1.35$.

Table 2: Comparison of the visual and auditory reaction times of the athletes according to the age variable (Oneway Anova Test)

\begin{tabular}{|c|c|c|c|c|c|c|}
\hline & & $\mathbf{N}$ & Mean. & Std. Dev. & p & Difference \\
\hline \multirow[t]{3}{*}{ VRT } & 15-18 age & 35 & 246,63 & 23,309 & \multirow{3}{*}{0,277} & \multirow{3}{*}{ - } \\
\hline & 19-22 age & 10 & 242,60 & 19,772 & & \\
\hline & 23 age and above & 3 & 225,33 & 6,028 & & \\
\hline \multirow[t]{3}{*}{ ART } & 15-18 age & 35 & 225,69 & 24,868 & \multirow{3}{*}{0,055} & \multirow{3}{*}{ - } \\
\hline & 19-22 age & 10 & 244,70 & 44,111 & & \\
\hline & 23 age and above & 3 & 200,00 & 6,083 & & \\
\hline
\end{tabular}

VRT: Visual Reaction Time, ART: Auditory Reaction Time

When Table 2 is examined, no statistically significant difference was found between the groups in terms of the age variable of martial arts athletes $(p<0.05)$.

Table 3: Comparison of visual and auditory reaction times of athletes according to body mass index variable (Oneway Anova Test)

\begin{tabular}{|l|l|c|c|c|c|c|}
\hline \multicolumn{2}{|c|}{} & $\mathbf{N}$ & Mean & Std. Dev. & p & Difference \\
\hline \multirow{3}{*}{ VRT } & Weak & 11 & 246,91 & 16,053 & & \\
\cline { 2 - 5 } & Normal weight & 27 & 247,96 & 25,334 & \multirow{2}{*}{0,152} & - \\
\cline { 2 - 5 } & Fat & 10 & 232,30 & 15,706 & & \\
\hline \multirow{3}{*}{ ART } & Weak & 11 & 226,64 & 26,020 & & \\
\cline { 2 - 5 } & Normal weight & 27 & 233,74 & 33,282 & \multirow{2}{*}{0,225} & - \\
\cline { 2 - 5 } & Fat & 10 & 214,20 & 24,845 & & \\
\hline
\end{tabular}

When Table 3 was examined, no statistically significant difference was found between the groups in terms of body mass index variable of martial arts athletes $(p<0.05)$. 
Table 4: Comparison of visual and auditory reaction times of athletes according to sports branch variable (Oneway Anova Test)

\begin{tabular}{|c|c|c|c|c|c|c|}
\hline & & $\mathbf{N}$ & Mean & Std. Dev. & $p$ & Difference \\
\hline \multirow[t]{6}{*}{ VRT } & Judo (1) & \multirow{12}{*}{8} & 267,13 & 15,160 & \multirow{6}{*}{0,001} & \multirow{6}{*}{$\begin{array}{c}1-2,1-3,1-5 \\
1-6,2-3,2-4,4-6\end{array}$} \\
\hline & Karate (2) & & 225,75 & 10,593 & & \\
\hline & Muay thai (3) & & 245,50 & 27,423 & & \\
\hline & Kick box (4) & & 253,75 & 11,696 & & \\
\hline & Taekwondo (5) & & 243,25 & 20,790 & & \\
\hline & Boxing (6) & & 231,38 & 19,741 & & \\
\hline \multirow[t]{6}{*}{ ART } & Judo (1) & & 256,38 & 37,348 & \multirow{6}{*}{0,005} & \multirow{6}{*}{$\begin{array}{l}1-2,1-4,1-6 \\
2-3,2-5,5-6\end{array}$} \\
\hline & Karate (2) & & 206,88 & 14,942 & & \\
\hline & Muay thai (3) & & 229,75 & 31,404 & & \\
\hline & Kick box (4) & & 223,38 & 14,192 & & \\
\hline & Taekwondo (5) & & 241,63 & 34,268 & & \\
\hline & Boxing (6) & & 210,25 & 16,334 & & \\
\hline
\end{tabular}

When Table 4 is examined, a statistically significant difference was found between the 1$2,1-3,1-5,1-6,2-3,2-4$ and 4-6 groups in the visual reaction time averages of the athletes according to the sport branch variable. On the other hand, no statistically significant difference was found in the visual reaction time averages between the other groups. A statistically significant difference was found between the 1-2, 1-4, 1-6, 2-3, 2-5 and 5-6 groups in the mean auditory reaction times $(p<0.05)$. On the other hand, no statistically significant difference was found in the mean auditory reaction times between the other groups $(\mathrm{p}<0.05)$.

Table 5: Comparison of visual and auditory reaction times of athletes according to sports age variable (Oneway Anova Test)

\begin{tabular}{|c|c|c|c|c|c|c|}
\hline & & $\mathbf{N}$ & Mean & Std. Dev. & p & Difference \\
\hline \multirow{6}{*}{ VRT } & $0-2$ years & 13 & 247,31 & 16,271 & \multirow{6}{*}{0,503} & \multirow{6}{*}{ - } \\
\hline & $3-4$ years & 12 & 248,00 & 24,506 & & \\
\hline & 5-6 years & 11 & 247,36 & 26,277 & & \\
\hline & $7-8$ years & 3 & 245,00 & 27,514 & & \\
\hline & 9-10 years & 4 & 238,75 & 30,923 & & \\
\hline & 11 years and above & 5 & 226,40 & 6,693 & & \\
\hline \multirow[t]{6}{*}{ ART } & $0-2$ years & 13 & 219,62 & 19,372 & \multirow{6}{*}{0,102} & \multirow{6}{*}{ - } \\
\hline & 3-4 years & 12 & 228,67 & 24,677 & & \\
\hline & $5-6$ years & 11 & 240,09 & 32,089 & & \\
\hline & $7-8$ years & 3 & 260,67 & 70,515 & & \\
\hline & 9-10 years & 4 & 224,50 & 23,558 & & \\
\hline & 11 years and above & 5 & 205,20 & 24,773 & & \\
\hline
\end{tabular}

When Table 5 was examined, no statistically significant difference was found between the groups according to the sports age variable $(\mathrm{p}<0.05)$. 
Table 6: Comparison of the visual and auditory reaction times of the athletes according to the success level variable (Oneway Anova Test)

\begin{tabular}{|c|c|c|c|c|c|c|}
\hline \multicolumn{2}{|c|}{ Variable } & $\mathbf{N}$ & Mean. & Std. Dev. & $\mathrm{p}$ & Difference \\
\hline \multirow[t]{6}{*}{ VRT } & World or European Championship Rating (1) & 2 & 239,50 & 6,36 & \multirow{6}{*}{0,002} & \multirow{6}{*}{$\begin{array}{l}2-4,2-5,2-6 \\
3-4,3-5,3-6\end{array}$} \\
\hline & International Championship Rank (2) & 7 & 226,14 & 6,28 & & \\
\hline & National Championship Rating (3) & 5 & 218,40 & 10,26 & & \\
\hline & Regional Degree (4) & 13 & 256,31 & 22,59 & & \\
\hline & Provincial Rank (5) & 7 & 249,57 & 29,99 & & \\
\hline & No Degree (6) & 14 & 250,07 & 14,91 & & \\
\hline \multirow[t]{6}{*}{ ART } & World or European Championship Rating (1) & 2 & 239,00 & 9,89 & \multirow{6}{*}{0,251} & \\
\hline & International Championship Rank (2) & 7 & 209,29 & 12,72 & & \\
\hline & National Championship Rating (3) & 5 & 222,60 & 32,16 & & \\
\hline & Regional Degree (4) & 13 & 235,46 & 34,563 & & \\
\hline & Provincial Rank (5) & 7 & 245,57 & 48,62 & & \\
\hline & No Degree (6) & 14 & 222,14 & 17,56 & & \\
\hline
\end{tabular}

When Table 6 is examined, a statistically significant difference was found between the 2$4,2-5,2-6,3-4,3-5$ and 3-6 groups in the visual reaction time averages of the athletes according to the variable of success degree. On the other hand, no statistically significant difference was found in the visual reaction time averages between the other groups. No statistically significant difference was found in the auditory reaction time averages $(\mathrm{p}<0.05)$.

\section{Discussion}

In this part of the study, the findings obtained are summarized and discussed in comparison with similar studies in the literature, and evaluations, opinions and suggestions about the results are given.

No statistically significant difference was found between the reaction times of the athletes in terms of age, body mass index and sports age variables $(\mathrm{p}<0.05)$.

According to the branch variable of the athletes, a significant difference was found between judokas and karate players in favor of karate players, between judokas and muaythaicians in favor of combatants, between judokas and kickboxers in favor of kickboxers, between judokas and taekwondoers in favor of taekwondo players, and between judokas and boxers in favor of boxers. On the other hand, a significant difference was found between karate players and fighter in favor of mauaithaists, between karate and kickboxers in favor of kickboxers, and between kickboxers and boxers in favor of boxers $(\mathrm{p}<0.05)$. Similarly, in the auditory reaction times of the athletes according to the branch variable, statistically, statistically, between judoka and karate players in favor of karate, between judoka and kickboxers in favor of kickboxers, between judoka and boxers in favor of boxers, between karate players and taekwonists in favor of taekwonists, between karate players and taekwonists in favor of taekwonists. A significant difference was found in terms of $(p<0.05)$. 
According to the success level variable of the athletes, a significant difference was found between the visual reaction times of those with international degrees, those with regional and provincial degrees, or those with no degrees in favor of those with international degrees $(\mathrm{p}<0.05)$. On the other hand, no statistically significant difference was found between auditory reaction times $(p<0.05)$.

Erbaş and Çakır (2021), in their study comparing various parameters of elite and non-elite taekwondo athletes, reported that there was no statistically significant difference between the visual reaction times of elite and non-elite taekwondo athletes $(\underline{14})$. In our study, it was observed that the visual reaction time improved as the level of success increased. There are many different methods for measuring visual reaction time. While measuring the visual reaction time, the environmental conditions must be regulated very well and completely free from the elements that may adversely affect the results $(\underline{15})$. Considering the necessity of reacting to instant position and movement changes of the opponent in branches such as taekwondo, kickboxing, boxing, muay thai and karate, it is thought that the visual reaction times of the elite level athletes should be better $(\underline{16})$. Therefore, it is thought that the lack of difference in visual reaction times between elite and non-elite athletes in the related study may be due to the measurement method.

Donovan et al. (2006) stated that the reaction times of martial arts athletes differed significantly when compared to sedentary ones in their study evaluating the leg strength and reaction times in martial arts athletes (17). In our study, it was observed that the reaction time improved as the level of success increased. Our findings overlap with this study and are supported by the findings of this study.

Atan and Akyol (2014), in their study comparing the reaction times of the athletes in different sports branches, reported that the reaction times of the athletes in other branches, except for the judo branch, did not differ ( $\underline{18})$. The findings of our study are also consistent with these findings. It can be said that this is due to the fact that Judo branch is mostly based on physical strength and technique, whereas other martial arts are based on quickness $(\underline{19})$.

Polat et al. (2018), in their study comparing the visual and auditory reaction times of elite taekwondo and kickboxers, reported that there was no significant difference between the visual reaction times of the athletes, however, the auditory reaction times of the taekwondo athletes were better than the kickboxers (20). In our study, no statistically significant difference was found between the visual and auditory reaction times of taekwondo and kickboxing athletes. It is thought that this situation is due to the fact that the relevant study covers elite athletes. In addition, it is thought that visual and auditory reaction times may also be due to measurement methods.

As a result, it can be said that as the success level of martial arts athletes increases, their visual and auditory reaction times improve, and when compared to judo, reaction time has a more important place in sports branches such as muay thai, karate, taekwondo, kickboxing and boxing. It is thought that the inclusion of reaction exercises by martial arts athletes in their training may contribute to more successful results. It is thought that 
the application of similar studies to different age, gender and level groups may contribute to the scientific literature.

It can be said that studies to investigate the effect of different trainings aimed at improving reaction speed on improving reaction speed can also contribute to the scientific literature. In addition to this, it is thought that researches to examine the effects of different reaction speed trainings on athletes in different age groups, different genders and different branches may contribute to the scientific literature.

\section{Conflict of Interest Statement}

There are no potential conflicts of interest on this article.

\section{About the Authors \\ Irfan Tamer Mülhim has Master of Science degree in sport science research field. \\ Dr. Furat Akcan is Associate Professor Doctor at Gaziantep University.}

\section{References}

1. Akbar KI, Soegiyanto S, Pramono H. Multimedia Development Based on Android in The Prevention and Handling of Injuries to Sports Players. Journal of Physical Education and Sports. 2019;8(4):38-43.

2. Guiney H, Machado L. Benefits of regular aerobic exercise for executive functioning in healthy populations. Psychonomic bulletin \& review. 2013;20(1):7386.

3. Musl TF. Peran Pelatih dalam Pembinaan Prestasi Atlet pada Organisasi Taekwondo Profesional: Universitas Gadjah Mada; 2017.

4. Yildiz M, Serdar U. Dövüş Sporu Yapan Millî Sporcularin Değerlere Bakış Açısı. Beden Eğitimi ve Spor Bilimleri Dergisi.23(1):119-30.

5. Cynarski WJ, Skowron J. An analysis of the conceptual language used for the general theory of martial arts-Japanese, Polish and English terminology. Ido Movement for Culture Journal of Martial Arts Anthropology. 2014;14(3):49-66.

6. Emru Tadesee M. Martial arts and adolescents: using theories to explain the positive effects of Asian martial arts on the well-being of adolescents. Ido Movement for Culture Journal of Martial Arts Anthropology. 2017;17(2):9-23.

7. Cojocariu A. Measurement of Reaction Time in Qwan Ki Do. Biology of Sport. 2011;28(2).

8. Mokha R, Kaur G, Sidhu L. Effect of training on the reaction time of Indian female hockey players. Journal of sports medicine and physical fitness. 1992;32(4):428-31.

9. Karatosun H. Antrenmanın fizyolojik temelleri. Baskı Isparta: Altıntuğ Matbaası. 2010:137-49.

10. Kaplan DS, Akcan F, Çakir Z, Kilic T, Yildirim C. Visuomotor and audiomotor reaction time in elite and non-elite badminton players. European Journal of Physical Education and Sport Science. 2017. 
11. Cuthbertson DW, Bershad EM, Sangi-Haghpeykar H, Cohen HS. Balance as a measurement of fatigue in postcall residents. The Laryngoscope. 2015;125(2):33741.

12. Pancar Z, Özdal M, Pancar S, Biçer M. Investigation of visual and auditory simple reaction time of 11-18 aged youth. European Journal of Physical Education and Sport Science. 2016.

13. Yüzer AF. İstatistik: Anadolu Universitesi; 2009.

14. Erbaş Ü, Çakir Z. Elit ve Elit Olmayan Tekvandocuların Üst Ekstremite Reaksiyon Süreleri ve Bacak Denge Düzeylerinin Karşılaştırılması. Uluslararası Güncel Ĕ̆itim Araştırmaları Dergisi.7(1):89-98.

15. Woods DL, Wyma JM, Yund EW, Herron TJ, Reed B. Factors influencing the latency of simple reaction time. Frontiers in human neuroscience. 2015;9:131.

16. Volodchenko O, Podrigalo L, Aghyppo O, Romanenko V, Rovnaya O. Comparative Analysis of a functional state of martial arts athletes. Journal of Physical Education and Sport. 2017;17(3):2142-7.

17. Donovan OO, Cheung J, Catley M, McGregor AH, Strutton PH. An investigation of leg and trunk strength and reaction times of hard-style martial arts practitioners. Journal of sports science \& medicine. 2006;5(CSSI):5.

18. Atan T, Akyol P. Reaction times of different branch athletes and correlation between reaction time parameters. Procedia-Social and Behavioral Sciences. 2014;116:2886-9.

19. Morales J, Ubasart C, Solana-Tramunt M, Villarrasa-Sapiña I, González L-M, Fukuda D, et al. Effects of rapid weight loss on balance and reaction time in elite judo athletes. International journal of sports physiology and performance. 2018;13(10):1371-7.

20. Polat SÇ, Akman O, Orhan Ö. A Comparison of the Reaction Times of Elite Male Taekwondo and Kickboxing Athletes. The Online Journal of Recreation and Sports. 2018;7(2):32-9. 
Creative Commons licensing terms

Authors will retain the copyright of their published articles agreeing that a Creative Commons Attribution 4.0 International License (CC BY 4.0) terms will be applied to their work. Under the terms of this license, no permission is required from the author(s) or publisher for members of the community to copy, distribute, transmit or adapt the article content, providing a proper, prominent and unambiguous attribution to the authors in a manner that makes clear that the materials are being reused under permission of a Creative Commons License. Views, opinions and conclusions expressed in this research article are views, opinions and conclusions of the author(s). Open Access Publishing Group and European Journal of Physical Education and Sport Science shall not be responsible or answerable for any loss, damage or liability caused in relation to/arising out of conflict of interests, copyright violations and inappropriate or inaccurate use of any kind content related or integrated on the research work. All the published works are meeting the Open Access Publishing requirements and can be freely accessed, shared, modified, distributed and used in educational, commercial and non-commercial purposes under a Creative Commons attribution 4.0 International License (CC BY 4.0). 